\title{
Completion Hak Asasi Manusia bukan Hak Asasi Manusia Kedunguan
}

\author{
Maman Sufirman ${ }^{1}$, Muhammad Fadly ${ }^{2}$, Nurman Saputra ${ }^{3}$, Muh Nur Yudistira T.N ${ }^{4}$ \\ Sekolah Tinggi Ilmu Hukum Amsir Parepare \\ Email:
}

mamansufirman23@gmail.com ${ }^{1}$, rahimpolri@gmail.com ${ }^{2}$,nurmansaputra271@gmail.com

${ }^{3}$, yudistiratn@gmail.com ${ }^{4}$

\begin{abstract}
The essence of this journal is about the resolution of human rights cases in Indonesia that still often ignore the human rights of victims. Settlement of human rights cases needs to be resolved fairly and pay attention to the value of human rights of all parties concerned. It's not just seeing who's in charge and that's what's being defended. The Settlement of Human Rights must be done fairly regardless of feathers. In this journal will raise the case of misrepresentation that occurred to 4 complainants Cipulir in Indonesia. Both were arrested and arrested on charges of murder they did not commit. This journal is the result of normative legal research. The results showed that legal protection against victims of misconduct has been regulated in the Law only justice can not be applied because of the lack of professionalism of investigators, the public and victims of misrepresentation who do not understand their rights and legal procedures.
\end{abstract}

Keywords: Justice; victim; human rights

\section{Latar Belakang Masalah}

Sejak kita terlahir kedunia, kita tidak pernah terlepas dari yang namanya diatur oleh sebuah hukum. Negara Indonesia sebagaimana ditegaskan dalam Pasal 1 ayat (3) Undangundang Dasar Negara Republik Indonesia Tahun 1945 merupakan Negara hukum, bukan negara berdasarkan kekuasaan belaka, oleh karena itu semua elemen dalam melaksanakan tindakan apapun harus dilandasi oleh hukum yang dapat dipertanggung jawabkan, tidak terkecuali persoalan Hak Asasi Manusia.

Hak Asasi Manusia adalah hak-hak yang sudah dimiliki oleh seseorang sejak ia masih dalam kandungan. Hak Asasi Manusia dapat berlaku secara universal. Dasar-dasar hak asasi manusia yang tertuang dalam deklarasi kemerdekaan Amerika Serikat atau Declaration of Indefendence of USA serta tercantum dalam Undang-Undang Dasar 1945 Republik Indonesia, seperti yang terdapat pada Pasal 27 ayat 1, Pasal 28, Pasal 29 ayat 2, Pasal 31 ayat 1, serta Pasal 30 ayat 1. Menurut Pasal 1 ayat (1) undang- undang Nomor 39 Tahun 1999 adalah seperangkat hak yang melekat pada hakikat dan keberadaan manusia sebagai makhluk Tuhan yang maha esa dan merupakan anugerahnya yang wajib dihorrnati, dijunjung tinggi dan di 
lindungi oleh Negara, hukum dan pemerintahan, dan setiap orang demi kehormatan serta perlindungan harkat dan martabat manusia.

Rule of law atau yang biasa disebut negara hukum sesungguhnya mempunyai kerangka tersendiri yang sifatnya universal dan bahkan cukup fundamental. Dalam sebuah pengakuan dan perlindungan terhadap hak-hak asasi, memapakarkan adanya aturan hukum yang mengatur tindakan negara atau pemerintah dalam arti tindakan aparatur negara tersebut dapat dipertanggung jawabkan secara hukum. Hal tersebut tentunya, akan membawa konsekuensi pada hukum pidana bagi aparatur negara. ${ }^{1}$

Hukum pidana bertujuan untuk melindungi dan menyelamatkan setiap individu atas adanya kejahatan dalam masyarakat, sehingga tujuan tersebut harus di tanamkan pada setiap aparat hukum agar tidak ada kejahatan yang lolos disebabkan kesalahan dalam penyidikan atau mungkin sebaliknya tidak ada kejahatan yang dilakukan individu tapi karena cara penyidikan yang keliru menyebabkan orang yang tidak bersalah menderita dan di hukum tanpa salah serta dicap sebagai penjahat. Lebih baik 10 penjahat lolos, daripada kekeliruan menghukum 1 orang yang tidak bersalah. ${ }^{2}$ Hal tersebut membuat kita miris melihatnya, apakah negara kita yang merupakan negara hukum masih mengingat kalimat bahwa setiap masyarakat di negara ini semua sama dimata hukum.

Perlindungan hak asasi manusia di negara Indonesia haruslah ditegakkan seadil-adilnya. Perlindungan hak asasi manusia, pada hakikatnya merupakan perlindungan terhadap korban dan menjadi salah satu bentuk perwujudan atas penghormatan, penegakan, dan penjaminan atas hak asasi manusia setiap individu. Dengan menunjukkan adanya persamaan prinsip dan ide hak asasi manusia, dapat digambarkan bahwa antara negara hukum dan penegakan hak asasi manusia merupakan satu mata uang dengan sisi yang berbeda. Perlindungan korban kejahatan dalam sistem hukum nasional sepertinya belum mendapatkan perhatian yang serius. Kedudukan korban dalam Sistem Peradilan Pidana Indonesia masih berorientasi pada perlindungan bagi pelaku (offender orientied). Hal ini terlihat dari sedikitnya hak-hak korban kejahatan memperoleh pengaturan dari perundang undangan nasional. Adanya ketidakseimbangan antara perlindungan terhadap korban kejahatan dengan perlindungan terhadap pelaku, merupakan penyimpangan dari Pasal 27 ayat (1) Undang-undang Dasar 1945, yang menyatakan bahwa "Segala warga negara sama kedudukannya di dalam mata hukum dan pemerintahan dan wajib menjunjung hukum dan pemerintahan itu dengan tidak ada kecualinya." Dalam jurnal ini penulis juga akan mengangkat sebuah kasus salah tangkap yang terjadi terhadap 4 orang pengamen Cipulir.

\footnotetext{
${ }^{1}$ Djoko Prakoso, 2006, Upaya Hukum yang di atur dalam KUHAP,Jakarta: Ghalia Indonesia, hlm. 512

${ }^{2}$ Soedjono Dirdjosisworo,2013, FilsafatPeradilan Pidana dan Perbandingan Hukum, Bandung : CV.Armico, hlm.17.
} 
Berdasarkan dari pemaparan hal - hal diatas, maka penulis tertarik untuk melakukan penelitian lebih lanjut secara normatif dalam penulisan jurnal "Completion Hak Asasi Manusia bukan Hak Asasi Manusia kedunguan"

\section{Metode Penelitian}

Metode penelitian ini menggunakan penelitian normatif, yakni penelitian hukum normatif merupakan penelitian hukum yang dilakukan dengan cara meneliti bahan pustaka atau data sekunder. Penelitian hukum normatif disebut juga penelitian hukum doktrinal. Penelitian yang dilakukan bersifat deskriptif analitis yaitu menggambarkan, menganalisis, menyimpulkan masalah-masalah yang menjadi objek penelitian. ${ }^{3}$

Penelitian hukum normatif berupa data-data yang diperoleh dari studi kepustakaan yang terdiri dari ketentuan-ketentuan atau peraturan-peraturan hukum, surat kabar, majalah hukum, jurnal, dan lain-lain, yang semuanya relevansi dengan permasalahan yang hendak diteliti.

\section{Analisis Dan Pembahasan}

\section{Konsep Dasar Hak Asasi Manusia}

Setiap manusia dilahirkan setara dalam martabat dan hak-haknya. Manusia diciptakan oleh Allah paling sempurna diantara ciptaan yang lain karena manusia dikaruniai akal dan hati nurani. Hendaknya setiap manusia memperlakukan manusia lain dengan baik. Setiap orang berhak atas semua hak dan kebebasan-kebebasan yang tercantum di dalam tanpa terkecuali, tanpa melihat warna kulit, jenis kelamin, bahasa, ras, agama, politik atau pandangan lain, asalusul kebangsaan atau kemasyarakatan, hak milik, kelahiran ataupun kedudukan lain. Selanjutnya, tidak akan diadakan pembedaan atas dasar kedudukan politik, hukum atau kedudukan internasional dari negara atau daerah dari mana seseorang berasal, baik dari negara yang merdeka, yang berbentuk wilayah-wilayah perwalian, jajahan atau yang berada di bawah batasan kedaulatan yang lain. ${ }^{4}$

Hak Asasi Manusia adalah hak-hak yang dimiliki manusia dan sudah melekat pada individu setiap mahluk yang dinamakan manusia ini. Dalam arti ini, semua manusia mempunyai hak-hak tersebut. Inilah sifat universal dari hak asasi manusia. Hak-hak tersebut tidak dapat dicabut (inalienable) artinya, seburuk apapun perlakuan yang telah dialami oleh seseorang atau betapapun bengisnya perlakuan seseorang, tidak akan berhenti menjadi manusia dan tetap memiliki hak-hak tersebut. Tapi bagaimana jika seseorang yang tidak bersalah tapi dituduh dan ditahan atas tindakan yang tidak pernah dia lakukan dan mereka tidak mendapatkan keadilan hukum dalam kasus hak asasi manusia yang mereka alami.

\footnotetext{
${ }^{3}$ Amiruddin dan H. Zainal Asikin, Pengantar Metode Penelitian Hukum, Jakarta:PT. Raja Grafindo Persada, 2006, hal. 118. ${ }^{4}$ Rhona K.M. Smith, Hukum Hak Asasi Manusia. PUSHAM UII, Yogyakarta. 2008, hal 1
} 


\section{Penegakan Hukum dan Keadilan di Indonesia}

Sudah menjadi konsumsi publik bahwa penegakan hukum dan keadilan di Indonesia masih sangat memprihatinkan. Bahkan aparat hukum dengan terang-terangan menampakkan ketidak adilan dalam penegakan hukum. Bukankah kita masih ingat kasus penyiraman air keras kepada Novel Baswedan, kasus hukum Munir, kasus penembakan mahasiswa Trisakti yang sampai sekarang belum menemui titik terang dan keadilan, dan penegakan hukum terhadap seorang nenek Minah disidang PN.Purwokerto dengan dakwaan pencurian 3 (tiga) butir kakao dari kebun milik suatu perusahaan. ${ }^{5}$ Bahkan masih banyak lagi kasus-kasus penegakan hukum yang keadilannya belum terwujud dan sampai sekarang menimbulkan pertanyaan dibenak masyarakat. Apakah didalam negeri kita ini masih bisa ditemukan yang namanya keadilan.

Setiap manusia harus menyadari dan menanamkan dalam benaknya bahwa setiap manusia itu berharga dan hak asasi setiap manusia itu harus diperjuangkan. Jangan hanya karena kepentingan diri sendiri atau negara kita mengesampingkan hak asasi dari setiap manusia. Negara harus mengutamakan hak asasi dari setiap masyarakatnya dan menegakkan hukum yang adil tanpa memandang siapa yang melakukan kejahatan. Sebuah pemufakatan jahat tidak dapat dilindungi oleh undang-undang. Jadi, apabila aparat negara yang melakukannya, secara otomatis (demi hukum), hak imunitas yang diberikan undang-undang bagi polisi tidak dapat diterapkan. Kalau mau diterapkan kepada jaksa dan hakim, maka kedua pihak ini pun harus bertanggungjawab secara pidana karena telah berbuat kesalahan, baik dalam menuntut maupun menjatuhkan putusan. Memang, kelemahan hukum Indonesia adalah tidak ada pengaturan yang jelas mengenai kesalahan menangkap ini secara khusus bagi polisi. Walaupun demikian, tetap saja, sebuah kejahatan harus dihukum.

Satjipto Rahardjo memberikan penjelasan dan solusi, bagaimana hukum itu supaya dapat berguna bagi masyarakat dan dapat ditegakkan. Beliau berpendapat bahwa reformasi hukum di indonesia belum berhasil, antara lain disebabkan masih maraknya korupsi, komersialisme dan commadification.Untuk mengatasi hal tersebut, penulis menawarkan suatu konsep pemikiran yang disebut dengan Hukum Progresif. Hukum Progresif dimulai dari suatu asusmsi dasar bahwa hukum adalah untuk manusia, bukan sebaliknya. ${ }^{6}$ Penegakan hukum dan keadilan merupakan persoalan yang serius bagi bangsa Indonesia. Untuk terwujudnya hal bangsa kita harus lebih memperbaiki dan memperhatikan faktor-faktor yang mempengaruhi penegakan hukum dan keadilan (Kasus korban salah tangkap pengamen Cipulir) di antara lain:

\footnotetext{
${ }^{5}$ Alamsyah, Bunyamin. 2013. Penegakan Hukum dan keadilan di Indonesia antara Harapan dan Kenyataan. Jurnal Hukum, Legalitas Edisi Juni2013 Volume IV Nomor 1, hal 36.

${ }^{6}$ Satjipto Rahardjo,Hukum Progresif, Sebuah Sintesa Hukumlndonesia, Genta, Yogyakarta, 2009, hlm.1
} 
a. Undang-undang yang Mengatur, yaitu karena peraturan-peraturan perundang-undangan yang mengatur mengenai perlindungan hukum terhadap korban salah tangkap belum mencerminkan asas peradilan yang cepat murah dan sederhana. Dapat dikatakan bahwa untuk dapat memperoleh ganti kerugian membutuhkan proses yang panjang karena pemohon harus menunggu kelengkapan berkas, yang tentunya membutuhkan waktu yang lama dan berbelitbelit serta membutuhkan biaya yang tidak sedikit.

b. Aparat Penegak Hukum dan Criminal Justice System, yaitu Aparat penegak hukum pada dasarnya ingin diakui eksistensinya ditengah-tengah masyarakat. Namun, dalam menjalankan tugas dan kewenangannya seringkali keluar dari aturan yang diatur dalam perundangundangan. Dalam mewujudkan tujuan hukum yaitu keadilan, kemanfaatan dan kepastian hukum. Masing-masing petugas hukum (Polisi, Jaksa, Hakim) meskipun tugasnya berbedabeda tetapi mereka harus bekerja dalam satu kesatuan sistem. Artinya, kerja masing-masing petugas hukum tersebut harus berhubungan secara fungsional. Karena seperti yang diketahui bahwa penyelenggaraan peradilan tersebut, adalah merupakan suatu sistem, yaitu suatu keseluruhan terangkai yang terdiri dari atas unsur-unsur yang saling berhubungan secara fungsional. Namun kenyataanya, aparat penegak hukum (polisi, jaksa, dan hakim) dalam menjalankan tugas dan kewenangannya tidak berhubungan satu sama lain.

c. Masyarakat Atau Korban Salah Tangkap yang Cendrung Tidak Mengerti Akan Haknya, yaitu karena pada umumnya masyarakat dan juga korban salah tangkap itu sendiri tidak mengetahui adanya ganti kerugian dari negara apabila dikenakan tindakan upaya paksa tidak sah atau salah tangkap oleh aparat penegak hukum dan ada pula masyarakat yang telah mengetahui hal tersebut, tetapi tidak mengetahui kemana harus mengadu/melapor dan bagaimana prosesnya untuk mendapatkan ganti kerugian hal ini menyulitkan dalam menerapkan pelaksanaan perlindungan hukum dalam hal ini adalah pemberian ganti kerugian dan rehabilitasi atas tindakan kasus salah tangkap.

d. Budaya, yaitu karena sebagian besar masyarakat yang pernah mengalami kasus salah tangkap atau error in persona, memilih untuk tidak menuntut ganti kerugian karena takuut jika harus menggunggat dan melawan aparat hukum serta dengan bebas saj mereka suda bersyukur tapi jika hal ini terus terjadi maka keadilan di negara ini tidak akan terwujud.

e. Psikologi, yaitu karena masyarakat pada umumnya kurang mempercayai aparat penegak hukum, khususnya masyarakat yang berpendidikan rendah mereka beranggapan bahwa hanya orang yang berduit saja yang akan mendapatkan keadilan. Stigma ini ada karena seperti itulah hukum di negara kita lebih mendahulukan orang berada dibandingkan masyarakat kelas bawah. 


\section{Perlindungan Hukum Terhadap Korban Salah Tangkap Menurut Aturan Hukum di Indonesia.}

Menurut Phillipus M. Hadjon bahwa perlindungan hukum bagi rakyat sebagai tindakan pemerintah yang bersifat preventif dan resprensif. Perlindungan Hukum yang preventif bertujuan untuk mencegah terjadinya sengketa, yang mengarahkan tindakan pemerintah bersikap hati-hati dalam pengambilan keputusan berdasarkan diskresi dan perlindungan yang resprensif bertujuan untuk mencegah terjadinya sengketa, termasuk penanganannya di lembaga peradilan. Perlindungan hukum merupakan gambaran dari bekerjanya fungsi hukum untuk mewujudkan tujuan-tujuan hukum, yakni keadilan, kemanfaatan dan kepastian hukum. ${ }^{7}$

Perlindungan hukum adalah suatu perlindungan yang diberikan kepada subyek hukum sesuai dengan aturan hukum, baik itu yang bersifat preventif maupun dalam bentuk yang bersifat represif, baik yang secara tertulis maupun tidak tertulis dalam rangka menegakkan peraturan hukum. Hakekatnya setiap orang berhak mendapatkan perlindungan dari hukum. Hampir seluruh hubungan hukum harus mendapat perlindungan dari hukum. Oleh karena itu terdapat banyak macam perlindungan hukum. Selama ini pengaturan perlindungan korban belum menampakkan pola yang jelas, dalam hukum pidana positif yang berlaku pada saat ini perlindungan korban lebih banyak merupakan "perlindungan abstrak" atau"perlindungan tidak langsung". Artinya berbagai rumusan tindak pidana dalam peraturan perundang-undangan selama ini pada hakekatnya telah ada perlindungan in abstracto secara langsung terhadap kepentingan hukum dan hak asasi korban. Perlindungan secara tidak langsung dalam peraturan hukum positif tersebut belum mampu memberikan perlindungan secara maksimal.

Menurut Yahya Harahap bahwa kekeliruan dalam penangkapan mengenai orangnya diistilahkan disqualification in person yang berarti orang yang ditangkap atau ditahan terdapat kekeliruan, sedangkan orang yang ditangkap tersebut telah menjelaskan bahwa bukan dirinya yang dimaksud hendak ditahanatau ditangkap. ${ }^{8}$ Sementara itu Sugeng mendefinisikan bahwa korban salah tangkap adalah seseorang atau sekelompok orang yang mengalami penderitaan fisik, mental, dan atau kerugian ekonomi yang diakibatkan kesalahan aparat negara dalam hal ini kepolisian dalam menangkap pelaku sebenarnya dengan kesewenang-wenang atau tidak berdasarkan undang-undang". ${ }^{9}$ Perlindungan Hukum Terhadap Korban Salah Tangkap Menurut kitab Undang-undang hukum acara pidana :

\footnotetext{
${ }^{7}$ Philipus M Hadjon, 2007, Perlindungan Hukum Bagi Rakyat Indonesia, Surabaya, Bina IImu, hlm. 10

${ }^{8}$ Yahya Harahap, 2009, Pembahasan Permasalahan dan Penerapam KUHAP Penyidikan dan Penuntutan, Jakarta : Sinar Grafika, hlm 45.

${ }^{9}$ Sugeng, 2013"Perlindungan Hukum Korban Salah Tangkap”,Makalah, Fakultas Hukum Universitas Pawyatan Daha, hlm 8.
} 
1). Ganti kerugian merupakan suatu upaya untuk mengembalikan hak-hak korban, yang karena kelalaian aparat penegak hukum telah salah dalam menentukan seseorang untuk dijadikan sebagai tersangka/terdakwa dalam suatu tindak pidana (error in persona). Menurut Pasal 1 Ayat 22 Kitab Undang- Undang Hukum Acara Pidana, yaitu: "Ganti kerugian adalah hak seseorang untuk mendapatkan pemenuhan atas tuntutannya yangberupa imbalan sejumlah uang karena ditangkap, ditahan, dituntut ataupun diadili tanpa alasan yang berdasarkan undang-undang atau karena kekeliruan mengenai orangnya atau hukum yang diterapkan menurut cara yang diatur dalam undang undang ini."

2). Rehabilitasi adalah sebagai sarana dan upaya untuk memulihkan kembali nama baik, kedudukan dan martabat seseorang yang telah sempat menjalani tindakan penegakan hukum baik berupa penangkapan, penahanan, penuntutan atau pemeriksaan di sidang pengadilan.

penegakan hukum dan keadilan pada korban salah tangkap yang terjadi kepada 4 orang pengamen cipulir

Kesalahan dalam penegakan hukum terjadi di Jakarta Selatan yang menimpa 4 orang pengamen Cipulir yaitu Fatahillah, Fikri, Andro Supriyanto alias Ucok dan Nurdin Prianto alias Benges. Para terdakwa mengaku di persidangan bahwa mereka disiksa dan dipaksa untuk mengaku sebagai pelaku ketika diperiksa oleh para penyidik. Selain itu ada juga keterangan dari saksi yang menyatakan bahwa pelaku pembunuhan terhadap korban bukanlah para terdakwa melainkan orang lain yang bernama lyan, Brengos dan Jubai. Melihat keseluruhan isi kasus ini, bisa dilihat terdapat beberapa isu menarik seperti adanya dugaan penyiksaan terhadap para terdakwa dan adanya dugaan salah tangkap yang dilakukan oleh penyidik. Salah tangkap yang 4 remaja tersebut menimbulkan konsekuensi hukum bagi para terpidana, selain dia dapat mengajukan Peninjauan kembali dan menuntut pembebasannya karena terpaksa menjalani hukuman atas tuduhan kesalahan yang tidak pernah mereka lakukan.

Perlindungan hukum terhadap keempat remaja ini sebenarnya dalam peradilan pidana di Indonesia sudah diatur di dalam Undang-undang No 8 Tahun 1981 tentang Kitab Undangundang Hukum Acara Pidana jo PP 27 Tahun 1983 Pelaksanaan Kitab Undang-undang Hukum Acara Pidana jo PP 92 Tahun 2015 tentang Perubahan Kedua Atas Peraturan Pemerintah No 27 Tahun 1983 tentang Pelaksanaan Kitab Undang-undang Hukum Acara Pidana yaitu dalam bentuk Ganti Kerugian dan Rehabilitasi.

Terjadinya salah tangkap terhadap orang-orang yang tidak sama sekali bersalah, bahkan lebih dari sekedar penangkapan, orang yang tidak bersalah tersebut terkadang mau tidak mau harus merasakan pahitnya penahanan dengan kurungan, menghadapi hukuman yang sama 
sekali tidak diperbuat oleh korban. Hal ini sudah pasti koban akan mengalami gangguan mental dan fisik. Setelah mendapat banyak kerugian kemudian pada akhirnya di ketahui terjadinya kesalahan Penyidik Polri dalam melakukan tugasnya sebagai penegak hukum, tetapi yang mereka lakukan hanya dengan membebaskan atau meminta maaf kepada korban salah tangkap tanpa melihat kerugian-kerugian yang diterima si korban. Hal tersebut sudah jelas bahwa polri sebagai penyidik tidak bertanggung jawab atas kesalahan yang diperbuat.

Selama 3 tahun mereka memperjuangkan keadilan. Tiga tahun bukan waktu yang singkat banyak hak dari korban salah tangkap ini yang telah direnggut. Setelah dibebaskan berselang tiga tahun Keempat pengamen Cipulir korban salah tangkap mengajukan gugatan praperadilan ke Pengadilan Negeri Jakarta Selatan. Ke empat pengamen itu minta gugatan ganti rugi dengan total Rp.750.900.000,00 (tujuh ratus lima puluh juta sembilan ratus rupiah). Biaya itu meliputi total kehilangan penghasilan sampai biaya makan selama dipenjara. Mereka memperjuangkan ganti rugi tersebut dalam sidang praperadilan di pengadilan negeri Jakarta Selatan. Tidak hanya tuntuan secara materi, pihaknya juga meminta pihak Polda Metro Jaya dan Kejaksaan Tinggi DKI Jakarta untuk mengakui semua kesalahan karena salah menangkap orang dan melakukan tindak intimidasi. ${ }^{10}$ Tapi hakim menolak gugatan itu dengan dalih kasus yang menimpa keempat pengamen ini telah kadaluwarsa. Hal ini secara terang-terangan menyampaikan kepada kita bahwa hak asasi manusia di negara ini masih diabaikan dan dikesampingkan. Korban salah tangkap telah disiksa dan ditahan atas tindakan yang tidak mereka lakukan.

Kita dapat melihat lemahnya kemampuan profesionalisme penyidik, masyarakat dan korban salah tangkap yang kurang mengerti haknya. Peraturan perundang-undangan yang mengatur setiap kasus hak asasi manusia belum mencerminkan asas peradilan yang cepat murah dan sederhana merupakan faktor penghambat dalam melaksanakan perlindungan hukum terhadap korban salah tangkap. Pemerintah selaku pihak yang memiliki otoritas dalam pembuatan, pembaharuan dan penyusunan perundang-undangan, diharapkan dapat segera melakukan penyederhanaan dalam hal prosedur dan tata cara pelaksanaan pemberian ganti kerugiankarena tata cara yang sebelumnya terkesan berbelit-belit sehingga terkesan menyulitkan dalam hal pengajuan ganti kerugian. Aparat penegak hukum sebagai pelindung, pengayom, penjaga tertib masyarakat diharapkan profesional dalam melakukan prosedur penangkapan, penahanan. Masyarakat atau korban salah tangkap diharapkan lebih tegas guna mendapatkan hak atas kekeliruan yang mengakibatkan pelanggaran hak asasi manusia bagi korban salah tangkap.

\footnotetext{
${ }^{10}$ lihat:https://news.detik.com/berita/d-4645764/gugatan-ganti-rugi-ditolak-ibu-korban-salah-tangkap-tidak-adil.
} 


\section{Penutup}

Negara harus mengambil langka serius dalam hal menegakkan hukum dan keadilan. Pemerintah selaku pihak yang memiliki kekuasaan penuh dalam pembuatan, pembaharuan dan penyusunan perundang-undangan, diharapkan untuk melakukan penyederhanaan dalam hal prosedur dan tata cara pelaksanaan pemberian ganti kerugian karena tata cara yang ada terkesan rumit sehingga terkesan menyulitkan dalam hal pengajuan ganti kerugian. Pemerintah diharapkan melakukan pembaharuan hukum terkait jangka waktu dalam mengajukan tuntutan ganti rugi. Karena tuntutan ganti kerugian atas tindakan pelanggaran hak asasi manusia tidak dapat diatur jangka waktu minimalnya. Karena hak tersangka/ terdakwa untuk mendapatkan keadilan atas tindakan pelanggaran tidak mesti dibatasi dengan jangka waktu. Hal ini merugikan terdakwa yang kurang mampu baik dari segi pendidikan, pengetahuan maupun finansial. Aparat penegak hukum sebagai pelindung, pengayom, penjaga tertib masyarakat diharapkan profesional dalam melakukan prosedur penangkapan, penahanan.

\section{Referensi}

Alamsyah. Bunyamin, Huda. 2013. Penegakan Hukum dan keadilan di Indonesia antara Harapan dan Kenyataan. Jurnal Hukum, Legalitas Edisi Juni 2013 Volume IV Nomor 1, hal 36.

Amiruddin dan Zainal Asikin. 2003.Pengantar Metode Penelitian Hukum. Jakarta: PT Raja Grafindo Persada.

Dirdjosisworo, Soedjono. 1984. Filsafat PeradilanPidana dan Perbandingan Hukum. Bandung : CV. Armico.

Harahap, Yahya. 2009. Pembahasan Permasalahan dan Penerapam KUHAP Penyidikan dan Penuntutan. Jakarta : Sinar Grafika,.

https://news.detik.com/berita/d-4645764/gugatan-ganti-rugi-ditolak-ibu-korban-salah-tangkaptidak-adil.

M Hadjon, Philipus. 2007. Perlindungan Hukum Bagi Rakyat Indonesia. Surabaya, Bina IImu.

Prakoso, Djoko. 2006. Upaya Hukum yang di atur dalam KUHAP. Jakarta: Ghalia Indonesia.

Raharjo, Satjipto. 2009. Ilmu Hukum. Bandung: PT. Citra Aditya Bakti.

Rhona K.M. Smith, dkk. 2008. Hukum Hak Asasi Manusia. Yogyakarta: PUSHAM UII.

Sugeng, 2013. Perlindungan Hukum Korban Salah Tangkap. Makalah, Fakultas Hukum Universitas Pawyatan Daha.

\section{Peraturan Perundang-undang}

Undang-undang Dasar Negara Republik Indonesia Tahun 1945. 


\section{Hukum dan HAM}

Undang-undang Nomor 8 Tahun 1981 tentang Undang-undang Hukum Acara Pidana (KUHAP).

Undang-undang Nomor 1 Tahun 1946 jo.Undang-undang Nomor 73 Tahun 1958 Tentang Kitab.

Undang-undang Hukum Acara Pidana (KUHAP).

Peraturan Pemerintah Nomor 27 Tahun 1983 Tentang Pelaksanaan Kitab Undang-undang Hukum Acara Pidana.

Peraturan Pemerintah Nomor 92 Tahun 2015 Tentang Perubahan kedua Atas Peraturan Pemerintah Nomor 27 Tahun 1983 Tentang Pelaksanaan Kitab Undang-undang Hukum Acara Pidana. 